\title{
枚葉式半導体洗浄装置内に形成される渦の周期構造
}

\author{
河内 俊憲 ${ }^{* 1}$, 福田 修也 ${ }^{* 1}$, 中野 裕介 ${ }^{* 2}$, 清水 義也 ${ }^{* 1}$, 永田 靖典 ${ }^{* 1}$, 柳瀬 眞一郎 ${ }^{* 3}$
}

\section{Periodical structure of vortices in a semiconductor single wafer spin cleaner}

\author{
Toshinori KOUCHI ${ }^{* 1}$, Naoya FUKUDA*1, Yusuke NAKANO*2, \\ Yoshiya SHIMIZU*1, Yasunori NAGATA*1 and Shinichiro YANASE*3

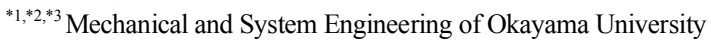 \\ 3-3-1 Tsushimanaka, Kita, Okayama-shi, Okayama 700-8530, Japan
}

\section{Received 15 May 2015}

\begin{abstract}
We experimentally and numerically investigated large-scale structures formed by vortices in a single wafer spin cleaner. The Q-criterion identified the vortices developed in the cleaner as the flow regions with positive second invariant of the velocity gradient tensor obtained by both the PIV and LES. The time-series two-components PIV data shows that small-vortices were clustered near and under the edge of the rotating disk and were periodically emanated from there to the housing wall of the cleaner. The emanation frequency was increased with increasing in the angular velocity of the rotating disk. Three-dimensional LES reveal that six longitudinal vortices were spirally developed from under the edge of the rotating disk to the housing wall. This structure stably rotated slower than the disk speed. Fourier analysis of the LES data agreed with that of the PIV data. This supports that the passages of the stable spiral vortices on the PIV measurement region resulted in the periodical emanation of the clustered small-vortices observed in the PIV. Such a very large-scale spiral structure will induce reattachment of contaminants on the wafer surface, and should be destructed for development of much higher efficient cleaner.
\end{abstract}

Key words : Rotating disk, Flow stability, Large-scale structure, PIV, LES

\section{1. はじめに}

近年，集積回路の微細化に伴い，半導体製造における洗浄方式が，“バッチ式”と呼ばれる 25 枚のウェー八を 一度に洗浄する方式から，“枚葉式”と呼ばれるウェー八を 1 枚毎に洗浄する方式に変更されつつある（服部， 2008). 半導体の製造では，トランジスタの配線間をショートさせる微小パーティクルを取り除くため，各工程間 でウェー八の洗浄が行われる．洗浄行程は回数が多く，その時間短縮・高精度化が半導体の生産性や品質を決定 づける．枚葉式洗浄では，ウェー八を超純水でリンスし，高速回転させながら乾燥空気を装置上部から流し乾燥 させる.この方式では，ウェー八を 1 枚毎に処理するため, 処理室の清浄度を保ちやすく, 前行程のパーティク ルの持ち越しによるクロスコンタミネーションが少ない．近年では高圧ジェット（Seike, et al., 2005）や極低温の 窒素エアロゾル（服部, 2008 や Hattori, 2014）をパーティクルに噴射するなどした “洗浄能力に関寸る技術”に関 して数多くの研究なされている，その一方で，洗浄によりウェーハから一旦はく離したパーティクルのウェーハ への再付着に関する研究は少ない.

枚葉式洗浄では乾燥時にウェー八とそれを保持するターンテーブルが高速回転する．回転円板上の流れは古く から研究され，円板上の層流境界層が乱流に遷移する過程で螺旋状に縦渦が発生することが知られている

(Schlichting, 1979) . 現在使用されているウェー八の口径は $300 \mathrm{~mm}$ と大きく, およそ 1000-2000 rpm の回転数で 乾燥を行うため, 円板端における回転レイノルズ数は $3 \times 10^{5}$ に達する. そのため円板上の境界層は容易に乱流遷 移し，円板上に螺旋渦が形成されうる．またウェー八は密閉された処理室内に設置されている．このような静止

No.15-00273 [DOI:10.1299/transjsme.15-00273], J-STAGE Advance Publication date : 20 August, 2015

${ }^{* 1}$ 正員, 岡山大学大学院 自然科学研究 科機械システム工学専攻（テ700-8530 岡山県岡山市北区津島中 3-3-1)

*2 学生員, 岡山大学大学院 自然科学研究科 機械システム工学専攻

*3 正員, フェロー, 岡山大学大学院 自然科学研究科 機械システム工学専攻

E-mail of corresponding author: kouchi@okayama-u.ac.jp 
したケーシングの中で円板を回転させた場合にも，ケーシング内に螺旋状の進行波が形成されることが知られて いる（Schouveiler, et al., 1999 や Gauthier, et al., 1999）。またこれら渦の発生要因とは別に, 洗浄機では乾燥空気を 排気するため，ターンテーブルとケーシングの間に比較的大きな排気スリットが存在している．そのためターン テーブルとケーシングの間の流れはテイラー・クエット流れ（Di Prima and Swinney, 1985）の様相を呈すること が予想され，ここにもテイラー渦が形成される恐れがある.

このような観点から洗浄機処理室内には様々な渦が発生し, この渦にのって一旦はく離したコンタミネーショ ンがウェー八に再付着寸る恐れがある. 洗浄機の運転条件によっては, この再付着がウェー八の洗浄度を決める 支配因子となる．しかしながら，先に述べたように洗浄機内の流れでは様々な要因により渦が形成される可能性 があり複雑で，処理室内の渦構造はほとんど分かっていない.

そこで近年, 我々のグループ（清水他, 2014）では実機サイズの枚葉式洗浄モデルを製作し，内部流動の PIV （Particle Image Velocimetry）計測を行い，形成される渦構造やその発生条件等を調べている．その結果，荻野ら （1997）が枚葉式洗浄機とよく似た半導体製造装置の一つである CVD 装置内で観測した結果と同様，円板の回 転速度の増加に伴い，そのポンピング効果により乾燥空気流は円板に吸い寄せられ，それに伴い時間平均的には 処理室円筒壁に沿って大規模な渦が形成されることが分かっている.またこれを抑制するのに必要な乾燥空気流 量に関しても実験的に求めている. しかしながら, これまでの計測では光学系の問題から, 円板近傍の流れと処 理室内壁近傍の流れを同時に計測することは困難であった。そのため計測結果に対する考察は主に時間平均場に 対してのみ行われ，渦の非定常な挙動はよく分かっていない，本研究では，これを計測できるように計測装置を 改良し, 円板端から処理室内壁までの広い領域を非定常に計測することで, これまで明らかになっていなかった 渦流の非定常挙動の解明を試みた. またPIV 計測に加えて, 洗浄機内流れの LES (Large Eddy Simulation) を行い, 実験結果と計算結果を相互に補完することで洗浄機内に存在する渦流がつくる大規模構造とその変化の様子を推 定したので，これを報告する.

\section{2. 実験方法および数値計算法}

\section{$2 \cdot 1$ 枚葉式洗浄装置モデル}

図 1 に本研究で用いた洗浄装置モデルの概要を示寸.図1 $1 \mathrm{a}$ は装置全体の系統図, 図 $1 \mathrm{~b}$ は測定部の詳細を示す. 測定部は洗浄機処理室を模擬した直径 $D=520 \mathrm{~mm}$, 高さ $470 \mathrm{~mm}$ の円筒からなっており, その中に半径 $R=165$ $\mathrm{mm}$ の円板が置かれている. なお本研究では円板上面の中心を原点とした円筒座標系 $(r, \theta, z)$ を用いる.

円板に吹き付けられる空気流は送風機により装置内を循環する. 送風機から送られた空気流はオリフィス流量 計を通り, 処理室の上方に設置された流路を通り, 長さ $1830 \mathrm{~mm}$ の助走区間に流入する. 助走区間入口には格子 間隔 $26 \mathrm{~mm}$ の整流用ハニカムが設けてあり, 助走区間で気流の乱れが減衰される. 本研究ではシリコンウェー八 とそれを保持するチャックテーブルは 1 つのものとして簡素化し, 厚さ $10 \mathrm{~mm}$ のアルミ製円板を回転円板とし て用いた. この円板下部には排気カバーが設けられ, その内側に 3 つの排気ポートが設置されている. 排気カバ 一と回転円板，また処理室の寸き間はそれぞれ $28 \mathrm{~mm} ， 45 \mathrm{~mm}$ である. 測定部に流入した気流は回転円板にぶつ かり，排気カバーと処理室の寸き間（以後これを排気スリットと呼ぶ）を通って排気カバー内に入り，排気ポー トからから送風機へと戻る.

実験は, 空気流量 $Q$ を $0.5 \pm 0.3,1.0 \pm 0.1,2.0 \pm 0.06,3.0 \pm 0.04 \mathrm{~m}^{3} / \mathrm{min}$ の 4 種類, 円板回転数 $n$ を $0 \sim 1300 \mathrm{rpm}$ で 変化させて行った. これは処理室の断面平均流速 $U=0.039 \sim 0.24 \mathrm{~m} / \mathrm{s}$, 円板角速度 $\Omega=0 \sim 136 \mathrm{rad} / \mathrm{s}$ に相当する. 本研究では主に $Q=1.0 \mathrm{~m}^{3} / \mathrm{min}, n=600 \mathrm{rpm}$ と $Q=0.5 \mathrm{~m}^{3} / \mathrm{min}, n=200 \mathrm{rpm}$ の結果を示す. これら条件はそれぞれ 円板の回転レイノルズ数 $R_{R}\left(=\Omega R^{2} / v\right)=1.1 \times 10^{5}$, 下降流レイノルズ数 $R_{D}(=U D / v)=2.7 \times 10^{3}$ と $R_{R}=3.8 \times 10^{4}$, $R_{D}=1.4 \times 10^{3}$ に相当する. なお $v$ は空気の動粘性係数である.

\section{$2 \cdot 2$ PIV 計測}

計測には PIV を用いた．PIV 用トレーサにはプロピレングリコール水溶液をヒータで温め霧化したスモークを 用いた. 本研究では, 円板から発生する渦の処理室内壁までの移流を調べることを目的とし, 図 $1 \mathrm{~b}$ 破線で示され る $r-z$ 平面を出力 $2 \mathrm{~W}$ の DPSS レーザ（Dantec 社 RayPower 2000）とハイスピードカメラ（Ditect 社 HAS-72D） 
a)

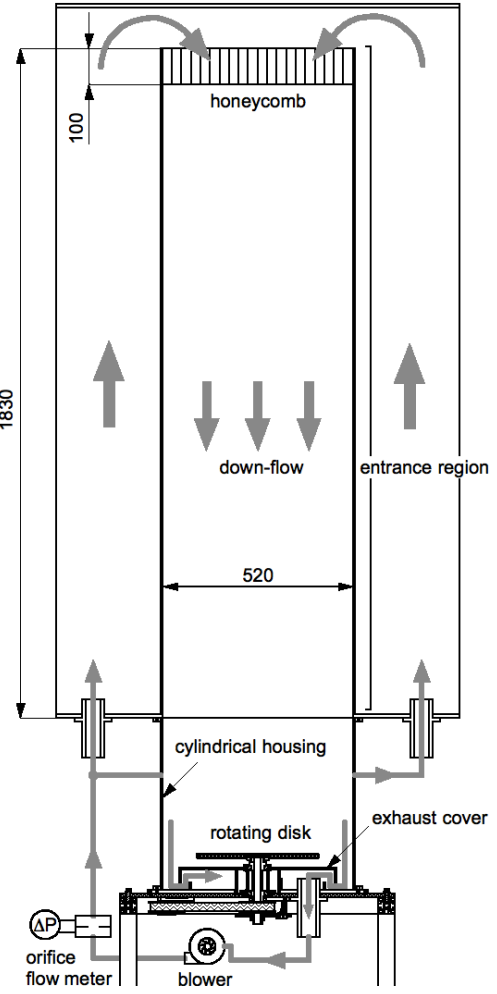

b)

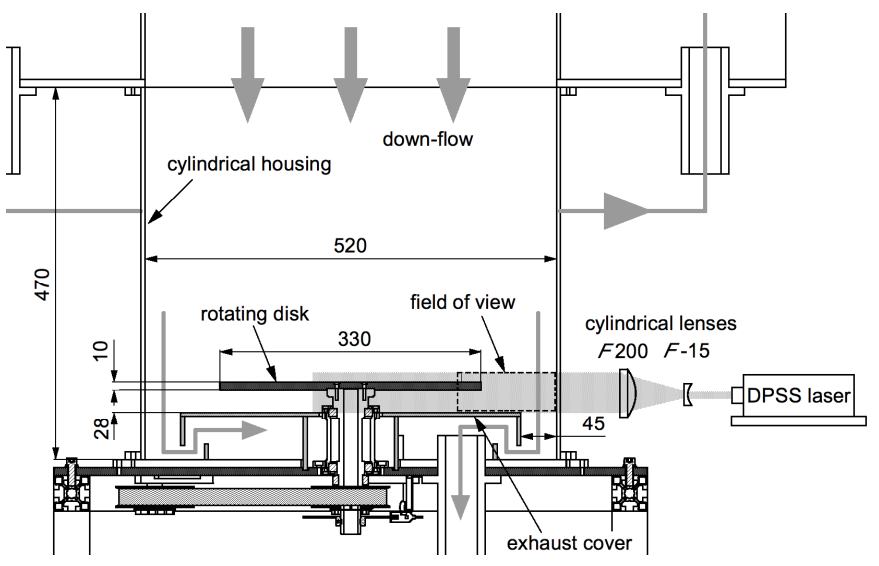

Fig. 1 Model of a single wafer spin clear used in this study. Fig. 1a shows the schematic diagram of the experimental apparatus. Arrows in this figure indicate flow circuit and its direction. Fig. 1b shows the details near the rotating disk. Both the optics and the measurement region for PIV are also shown in this figure.

を用いて非定常に可視化した. レーザビームはシリンドリカルレンズ群 (凸レンズ $f=200 \mathrm{~mm}$ とロレンズ $f=-15$ $\mathrm{mm}$ ）により幅 $50 \mathrm{~mm}$ のシート形状にし，円板回転軸を通るように円筒容器外から入射させた．一般にレーザシ 一ト厚さは光量の確保やシートの 2 次元性を保つため出来る限り薄く寸る. しかしながら, 本研究の $Q=1.0$ $\mathrm{m}^{3} / \mathrm{min}, n=600 \mathrm{rpm}$ 相当の条件では回転円板近傍において, 回転円板の周速度 $U_{\theta}=10 \mathrm{~m} / \mathrm{s}$ に代表されるシート 面外の速度成分が，空気流の下降流速 $U=0.08 \mathrm{~m} / \mathrm{s}$ に代表されるシート面内の速度成分に比べ非常に大きい，そ のためシート厚さが薄くなると円板近傍において粒子のシート面外への抜けが顕著になり PIV 解析が行えなくな る. そこでシート厚さを $3 \mathrm{~mm}$ と厚く寸ることで，円板近傍における粒子の面外方向への抜けを防いだ.

ハイスピードカメラはこのレーザシートに対して垂直になるように設置した．本研究ではレーザ入射位置は固 定し, 図 $1 \mathrm{~b}$ の破線部で示される排気ポートに近い領域の計測を行った. 当初, 流れの状態は排気ポートのある所 とない所で異なる恐れがあり，撮影断面を変えた試験を行うことも検討された．しかしながら後述する数值計算 の結果より, 排気ポートの非軸対称性の影響は排気カバーにより軽減され，ほとんど見られなかったので，本研 究ではこの位置のみの計測を行った. なお排気ポートと計測位置の相対的な関係は参考文献（清水他, 2014）に詳 しい. カメラには大口径 Cマウントレンズ（YMV5095： $f=50 \mathrm{~mm}, F / 0.95$ ）を取り付け，13,592 枚の粒子画像 を $n<1000 \mathrm{rpm}$ に対してはフレームレート $2000 \mathrm{fps}, n \geq 1000 \mathrm{rpm}$ に対しては $4000 \mathrm{fps}$ で撮影した. 粒子は円筒処 理室の曲面を通して撮影されるため, 円筒壁近傍では画像上に歪みが生じる．本研究ではこの歪みを試験前に撮 影したドット間隔 $5 \mathrm{~mm}$ のターゲット板の画像を用いたカメラキャリブレーションにより補正している．本研究 ではこの画像変形に加えて，レーザシートの強度むらの影響を軽減するため，1 回の試験で得られた画像から平 均画像を作成し，各粒子画像をこの平均画像で除してから PIV 演算を行った.

図 2a にこれら画像補正を行った後の $U=0.078 \mathrm{~m} / \mathrm{s}, \Omega=62.8 \mathrm{rad} / \mathrm{s}$ の条件（ $Q=1 \mathrm{~m}^{3} / \mathrm{min}, n=600 \mathrm{rpm}$ 相当）に おける典型的な粒子画像を示す．図中左上の粒子が存在しない長方形の領域が回転円板である. 図右側に処理室 内壁，下側に排気カバーが存在しており，空気流は画像上方から下向きに流れている．このような粒子画像を用 いて PIV 解析を行った． PIV 解析には商用ソフト（Ditect 社 Flownizer2D）を用いた．速度ベクトルの算出には再 帰相関法の一種である全画像変形法（Scarano, 2002）を用いた。 なお相互相関係数の計算には直接相関法を用い 
a)

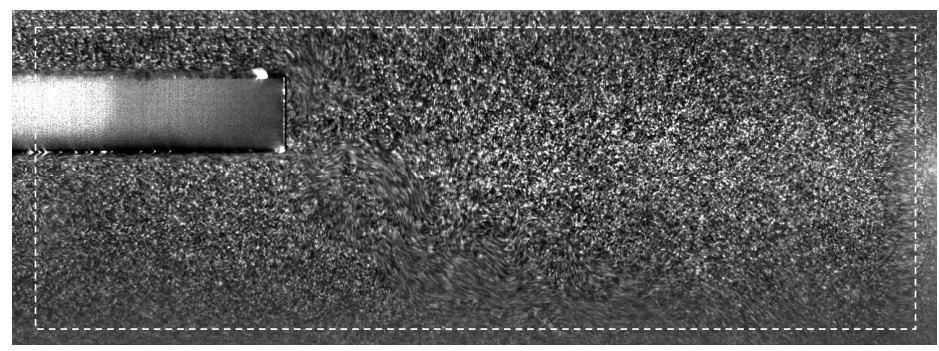

b)
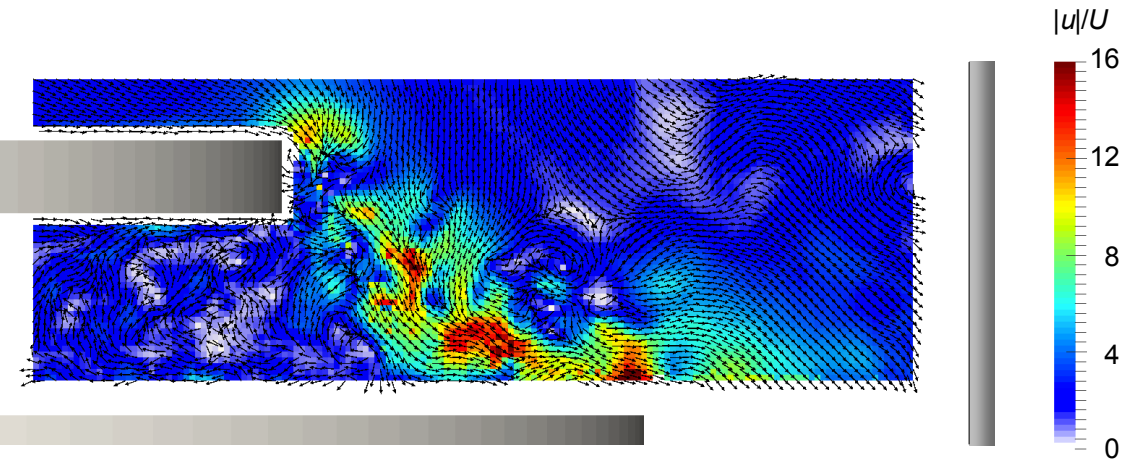

c)

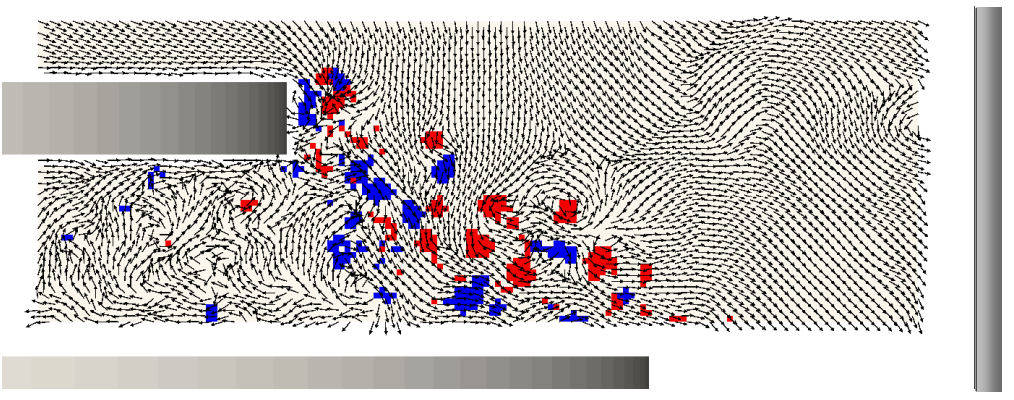

Fig. 2 a) Typical postprocessed instantaneous particle image, b) the instantaneous velocity distribution obtained from Fig. $2 a$, and c) the positive regions of the second invariant of the velocity gradient tensor $\left(Q_{2}\right)$ obtained from Fig. 2b. Dashed rectangular in Fig. 2a shows the region where the PIV calculation were performed. In Fig. 2b, the color contour indicates the magnitude of the velocity normalized by $U$, and the arrows indicate the directions of the velocities. In Fig. 2c, the red and blue regions are where the counterclockwise vortices and the clockwise vortices are observed, respectively.

ている.ベクトルは検査領域 $32 \times 32$ pixels，探査領域 $52 \times 52$ pixels とし，検査領域を $75 \%$ オーバーラップさせな

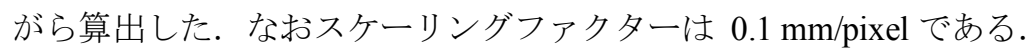

図 $2 \mathrm{~b}$ に図 $2 \mathrm{a}$ の粒子画像に PIV 解析を適用して得られた瞬時速度場を示す。カラーコンターは管断面平均流速 Uで規格化された速度の大きさ，また矢印は流れの向きを表している．図中上方から流れてきた空気流は回転円 板にぶつかり外筒壁へと向きを変えている. 回転円板端で流速は加速し, 円板端から排気スリットへ向かって, 速度の速い領域が存在している. その速度は排気力バー端近傍で最大で管断面平均速度の 15 倍にも達している. またベクトルの向きからこの高速の流れの外側, また回転円板と排気カバーの間の領域に多数の渦が存在してい ることが分かる．なおこの図では回転円板は紙面手前側に向かって回転している．また図 $2 \mathrm{c}$ は図 $2 \mathrm{~b}$ に対応する $Q_{2}$ 值の分布を示している。これに関しては後述する.

\section{$2 \cdot 3$ LES 計算}

本 PIV 計測は非定常計測ではあるけれど, 円板近傍から管壁までの 2 次元的な流れの挙動しか把握できない. 実際の流れは, 円板の回転に伴う $\theta$ 方向の流れのため 3 次元的な構造をしており，本 PIV はその 3 次元構造の 一部を時系列に追いかけているに過ぎない。そこで PIV 計測に加え 3 次元数值計算を行い, 実験と計算を相互に 補完することで, 現実に洗浄機内に形成される流れの 3 次元構造のより正確な推定を試みた. 
本研究では, オープンソースの数值計算ツールである OpenFOAM (2015)により, サブグリッドスケールモデル として Smagorinsky モデル（モデル定数 $C s=0.167 ）$ (Smagorinsky, 1963)を用いた Large Eddy Simulation（LES）を 行った. OpenFOAM では空間の離散化に, 物理量を節点に定義する有限体積法が用いられ，セル境界面の值を境 界面を隔てた節点における物理量から推定し, 計算を行う. 本研究では, 対流項流束の算出に 1 次精度風上法, 粘性項流束の算出に線形内挿（差分法でいうところの 2 次精度中心差分）を用いた. 時間積分には Euler 陰解法 を使用し，圧力-速度の連成には非直交補正を行った PISO 法 (Issa, 1986)を用いた.

計算には非構造格子を用いた. 計算格子はCAD で設計した実験装置の3D 形状 (STLデータ)を利用し, NETGEN (2015)により表面格子を, enGrid (2015)により空間格子を作成した. 計算領域は図 1a における助走区間から排気 ポートまでとし，助走区間入口に実験条件で規定される流量となる一様流を与え，計算を行った．本研究におけ る LES では空気流量を $Q=0.5 \mathrm{~m}^{3} / \mathrm{min}$ で固定し, 円板回転数を $n=200,500,800 \mathrm{rpm}$ と変えた. 空間格子の代表 的なスケールは, 回転円板近傍で $2 \mathrm{~mm}$, その他の領域で $8 \mathrm{~mm}$ 程度である. 非構造格子を用いる場合, 一般的に 物体表面に薄いプリズム格子を積層し境界層を解像寸る. 本計算では計算コストの観点から境界層用プリズム格 子を貼っていないため，回転円板上に形成される境界層や乱流遷移過程で生じる縦渦の構造は正確に解像できな い. 本計算では主に格子で解像できる洗浄機内に形成される大規模な渦構造に着目する. なお総格子点数は境界 層用プリズム格子を形成していない本計算格子でもおよそ 450 万点である.

\section{3. 結果と考察}

\section{$3 \cdot 1 Q_{2}$ 值による渦領域の同定}

本研究では前述したようにゴミの再付着を引き起こしうる洗浄機内に形成される渦構造に着目寸る. そこで PIV 計測・LES 計算の両データから速度勾配テンソルの第 2 不変量, 以下に定義される $Q_{2}$ 值を算出し, 旋回がせ 儿断に勝る領域を同定した（辻他, 2009）.

$$
Q_{2}=\frac{1}{2}\left(\boldsymbol{\Omega}_{i j} \boldsymbol{\Omega}_{i j}-\boldsymbol{S}_{i j} \boldsymbol{S}_{i j}\right)=\frac{\partial u_{r}}{\partial r} \frac{\partial u_{z}}{\partial z}-\frac{\partial u_{r}}{\partial z} \frac{\partial u_{z}}{\partial r}
$$

ここで $\Omega_{i j}$ は渦度テンソル, $S_{i j}$ はひずみ速度テンソルである. なお PIV 計測においては得られる速度が $r-z$ 平面内 の $u_{r}, u_{z}$ のみであるので, 2 次元性を仮定し式 1 の右辺の形式を用いた. $Q_{2}>0$ のとき旋回流がせん断より卓越す る. $Q_{2}$ 值により旋回が卓越する領域の同定は可能となるが， $Q_{2}$ 值のみでは旋回の向きまでは特定できない. そこ で $Q_{2}$ 值に加えて周方向渦度 $\omega_{\theta}$ を算出し, 時計回りの旋回領域 $\left(Q_{2}>0\right.$ かつ $\left.\omega_{\theta}<0\right)$ と反時計回り $\left(Q_{2}>0\right.$ かつ $\left.\omega_{\theta}>0\right)$ を区別した.

図 2c にその結果を示寸. 図は図 $2 \mathrm{~b}$ の瞬時速度場から算出した $Q_{2}$ 值分布で, $Q_{2}>5000$ の時計回りの旋回領域 を青, 反時計回りの旋回領域を赤で示してある. 図より流速が速い円板端から排気スリットにかけた帯状の領域 に, 多数の渦が存在していることが分かる. またこれら渦の回転の向きに着目寸ると, 渦層の外縁側に赤色で示 される反時計の渦が多く, 内縁側に青色で示される時計回りの渦が多い. また円板と排気カバーの間の領域では 速度べクトルは規則正しく並ばず，渦があるように見えるが， $Q_{2}$ 值自体は小さい，この図より，円板端で生成 された微小な渦は, 主に平均流にのって移動し, 排気スリットに吸い込まれていることが予想される. これを調 べるため, $Q_{2}$ 值により同定した旋回領域の時間変化を次に調べた.

\section{$3 \cdot 2$ 渦領域の周期変化}

図 3 に $Q_{2}$ 值により同定した旋回流領域の時間変化を示す. 前述と同様 $Q_{2}>5000$ で時計回りの旋回領域を青, 反時計回りの旋回領域を赤で示してある. また図には併せて, $(r, z)=(197.8 \mathrm{~mm},-18.8 \mathrm{~mm})$ の位置（図中×）にお ける $z$ 方向の変動速度 $u_{z}{ }^{\prime}$ の時系列データも示してある. なお $z$ は円板上向き（上流側）を正としており， $u_{z}{ }^{\prime}<0$ が下降流を意味していることに注意されたい. 図 3a を見ると図 $2 \mathrm{c}$ とはとの様相が異なり，渦領域は円板端から 排気スリットの方へ伸びてはおらず，円板近傍に留まっている．そして円板と外筒壁の間の広い領域において， 上方から流入する空気流がそのまま排気カバーに達している．時間の経過に伴い，この渦領域は大きく外筒壁側 一放出され，渦領域が処理室内に広がる（図 3b，3c）。さらに時間が経過すると下降流が渦領域を分断するよう 


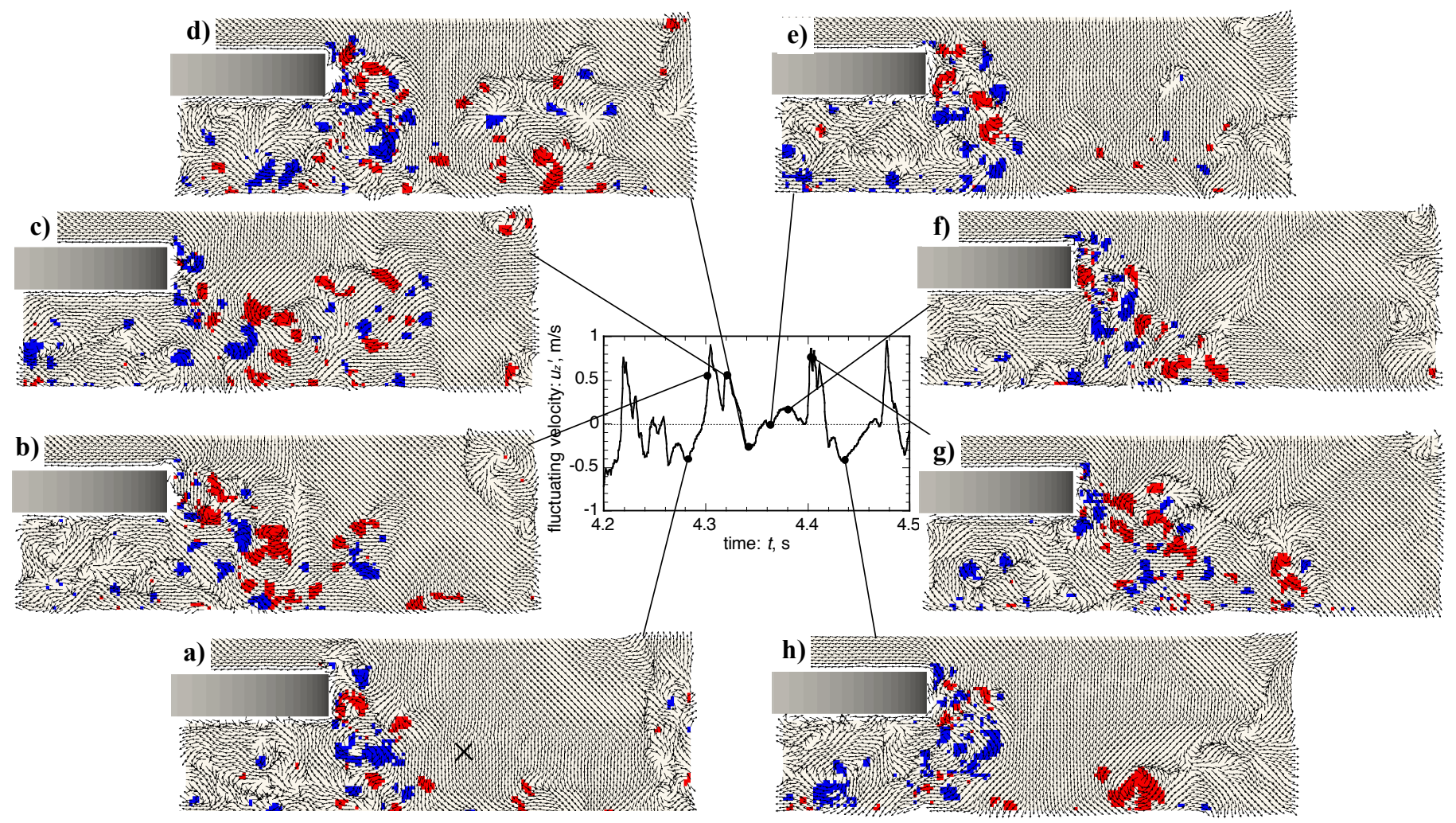

Fig. 3 Time series of the positive $Q_{2}$ distributions and fluctuating velocity of the $z$ component. The red and blue regions in the contour maps are the counterclockwise vortices and the clockwise vortices, respectively. Fig. $3 \mathrm{a}$ is the result at $t=4.28 \mathrm{~s}$ after the measurement were started. Figs. $3 \mathrm{~b} \sim 3 \mathrm{~g}$ are those at $t=4.3 \sim 4.4 \mathrm{~s}$ with its intervals of $0.02 \mathrm{~s}$, and Fig. $3 \mathrm{~h}$ is that at $t=4.44 \mathrm{~s}$. In Figs. $3 \mathrm{a}, 3 \mathrm{e}$ and $3 \mathrm{~h}$, the vortices were concentrated near the rotating disk. On the other hand, the vortices existed over the entire region of the housing. The region where the vortices were concentrated periodically changed.

に円板端近傍に流れ込み（図 3d)，再度，図3aでみたような渦領域が円板と排気カバーの間に押し込まれたよう な状態となる (図 3e)．図 3f 3h，また $u_{z}^{\prime} の$ 時系列データをみるとこれが周期的に繰り返されていることが分か る.

この周期性を調べるため $u_{z}^{\prime}$ のフーリエ解析を行った．その結果を図 4 に示寸．図には $\Omega=62.8 \mathrm{rad} / \mathrm{s}$ の結果の みならず, $\Omega=10.5 \sim 104.7 \mathrm{rad} / \mathrm{s}$ の結果も併せて示してある. 図の横軸は周波数で, 縦軸は $u_{z}$ のパワースペクトル 密度である. なお図のパワースペクトル密度は全計測時間（2000 fps の場合およそ $6.5 \mathrm{~s} ）$ のデータから $1 \mathrm{~s}$ 間のデ 一タをデータ長の $50 \%$ をオーバーラップさせながら切り出しスペクトルを求め, それらの平均をとった結果であ る. 従って, 本解析の周波数分解能 $d f$ は $1 \mathrm{~Hz}$ である. 図より全ての $\Omega$ 条件において明確なスペクトルのピーク が見られ周期性があることが分かる．またその周波数は角速度の増加に伴い増加している.

このように洗浄機内では，下降流が優勢になり渦領域が円板と排気カバーの間に押し込まれている状態と，円 板と排気力バーの間の流れの放射流が優勢になり渦領域が管壁側へ放出され渦領域が処理室全体に広がっている 状態が周期的に繰り返される. またその周期は円板の角速度が増加するに伴い短くなることが実験的に明らかに なった. しかしながら，このような周期的な変化が軸対称的に生じているとは考えにくく，流れ場の何らかの 3 次元性に起因するものではないかと考え, 3 次元数值計算を行った.

\section{$3 \cdot 3$ 渦領域の三次元構造}

図 5 にLES で得られた結果を示す. 図は $U=0.04 \mathrm{~m} / \mathrm{s}, \Omega=20.9 \mathrm{rad} / \mathrm{s}\left(Q=0.5 \mathrm{~m}^{3} / \mathrm{min}, n=200 \mathrm{rpm}\right.$ 相当）にお ける $Q_{2}=200$ の等值面を示している. 図より, この条件においては回転円板の周りに $6 つ の$ 渦管が円板端から外 筒壁へ伸びていることが分かる．この渦管は円板の回転方向から見て時計周りの旋回している．そしてこの渦管 は流れ場に安定に存在しており, 円板の回転角速度よりはるかに遅い角速度で円板と同じ方向に回転していた。 このような $6 つ の$ 渦構造は, 本研究で行った計算では全ての条件 $\left(Q=0.5 \mathrm{~m}^{3} / \mathrm{min}, n=200,500,800 \mathrm{rpm}\right)$ にお 


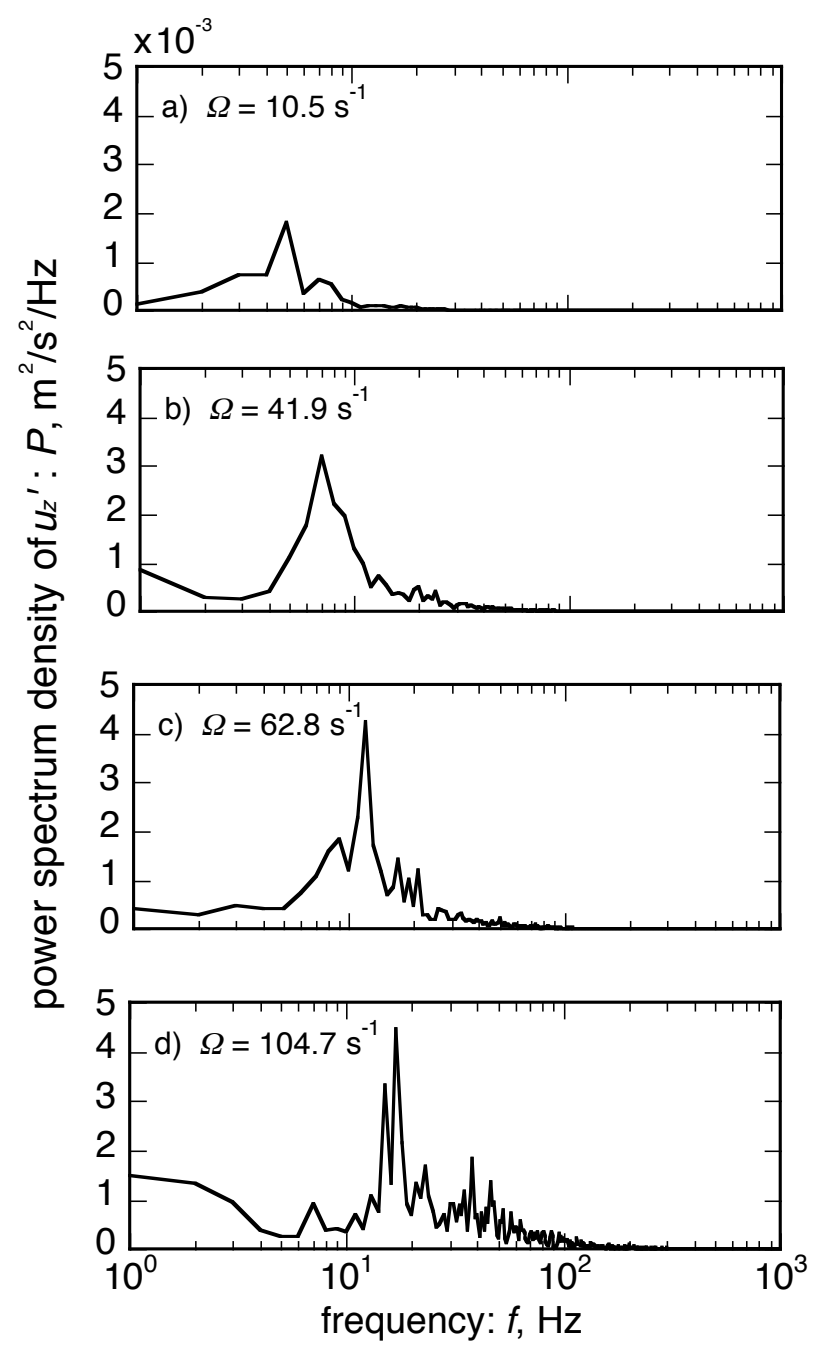

Fig. 4 Power spectral density of fluctuating velocity $u_{z}$ ' for various $\Omega$ case. Spectral peaks are observed in each $\Omega$ case. The frequencies on the spectral peaks increases with increasing $\Omega$.

いて観測された. 2 次元 PIV 計測における $u_{z}{ }^{\prime}$ の周期性は，この LES に見られる安定な渦構造がゆっくり回転し， 計測断面を通過することに起因するのではないかと考えられる。そこで計算においても，特定の $r-z$ 断面におけ る $u_{z}$ 'の時系列データのフーリエ解析を行い, 実験と比較した. その結果を図 6 に示す. なお PIVデータのフーリ 工解析結果における周波数分解能は $d f=1 \mathrm{~Hz}, \mathrm{LES}$ データでは $d f=0.1 \mathrm{~Hz}$ と異なっており, パワースペクトル密 度は $z$ 方向の速度の分散 $\sigma_{u z}{ }^{2}$ と周波数分解能 $d f$ を用いて無次元化している. 図より計算では $3 \mathrm{~Hz}$ に急峻なスペク トルのピークがあることが分かる. 図 5 で見た大規模渦の構造は 6 つの渦を有し，この計算条件では移流速度 $\Omega_{\theta} \sim 3 \mathrm{rad} / \mathrm{s}$ で回転していた. 従って, $3 \mathrm{~Hz}$ に見られるスペクトルのピークはこの渦構造の移流に起因するもので ある. 計算結果と実験結果を比較すると, 計算に見られたこのスペクトルのピークは実験にも見られる. 計算に おけるスペクトルのピークは実験に比べかなり急峻であるものの，その位置やスペクトルの定性的な傾向は非常 に良く一致している．また回転円板の角速度 $\Omega$ を変えた計算から，この大規渦模構造は $\Omega$ を変えても洗浄機内 に形成され続け， $\Omega$ の増加に伴いその移流速度も増加することが分かっている. 図 4 で見たスペクトルのピーク とその $\Omega$ の変化に対する変化の傾向も本計算結果をサポートしており, 実験においても図 5 に見られるような大 規模構造が存在していると結論できる.

最後にこれら結果のまとめとして, 2 次元 PIV 計測の 3 次元再構築を試みた. その結果を図 7 に示す. 図は $U=$ $0.04 \mathrm{~m} / \mathrm{s}, \Omega=20.9 \mathrm{rad} / \mathrm{s}$ における円板と排気力バーの間, $z=-0.02 \mathrm{~m}$ における $r-\theta$ 断面の $u_{z}$ を示している. 図には 
a)

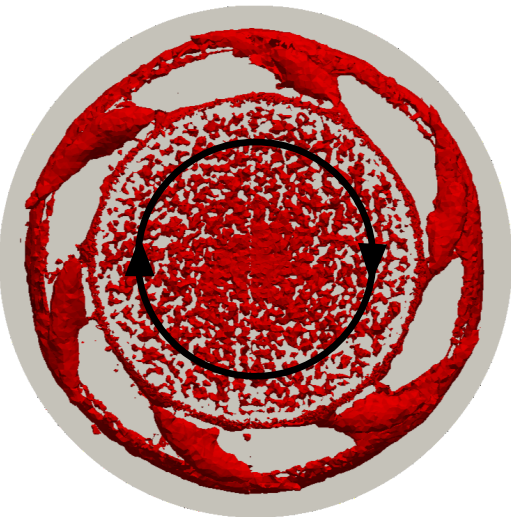

b)

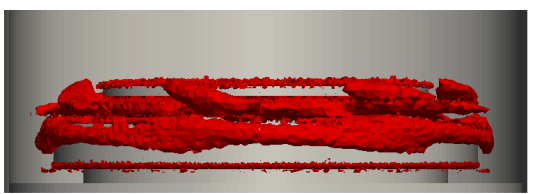

c)

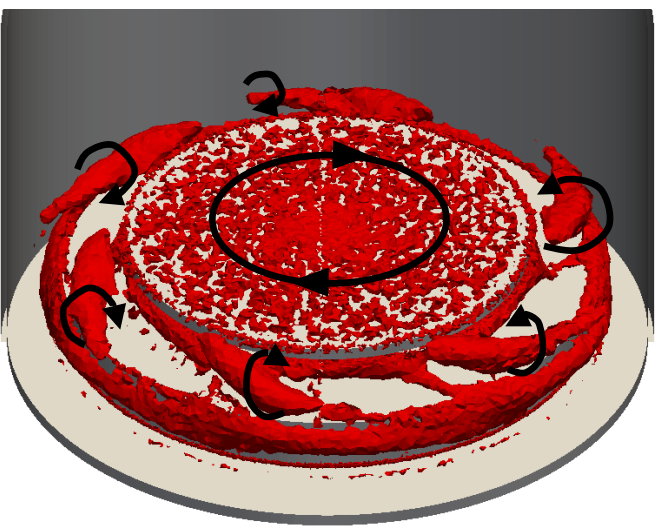

Fig. 5 Snapshot of three-dimensional vortex structures observed in LES of the modeled single spin cleaner using Smagorinsky subgrid-scale model under the conditions of $U=0.04 \mathrm{~m} / \mathrm{s}$ and $\Omega=$ $20.9 \mathrm{rad} / \mathrm{s}$. The vortical regions are identified with the second invariant of velocity gradient tensor over 200. The disk rotates in a clockwise direction in this figure.

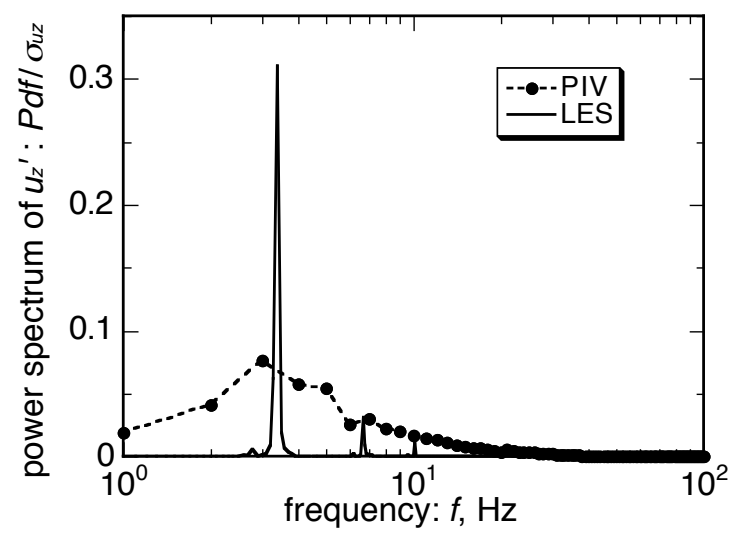

Fig. 6 Comparison of the power spectral densities obtained by the PIV (symbols) and LES (line). The power spectral densities are normalized by the variance of $u_{z}$ and $d f$.

併せて計算結果（図 7a）も示してある. PIV データの 3 次元再構築はテイラーの凍結仮説を仮定し, 2 次元的に 得られた $r-z$ 断面のデータを回転させることにより行った. 本計測では面外方向の速度成分である $u_{\theta}$ は計測して いないため, ここでは計算で見られた大規模構造の移流速度 $\left(\Omega_{\theta}=3 \mathrm{rad} / \mathrm{s}\right)$ の剛体回転を計測領域全体に仮定し, 時間 $t$ と計測座標 $(r, z)$ とから以下の式で 3 次元空間座標 $(x, y, z)$ を求めデータの再構築を行った.

$$
\begin{aligned}
& x=r \cos \left(-\Omega_{\theta} t\right) \\
& y=r \sin \left(-\Omega_{\theta} t\right) \\
& z=z
\end{aligned}
$$

なお実際の流れでは，場所によって $u_{\theta}$ が異なるため，厳密な 3 次元構造ではないことに注意されたい.

図 5 でも見たように，渦管は円板の回転方向から見て時計周りの旋回しており， $u_{z}>0$ の領域（赤）と $u_{z}<0$ の 領域（青）が隣り合う領域がこの渦管を表している. 実験と計算を比較すると，定性的に非常に似た構造になっ ている，両者とも白い破線で囲まれた大規模渦構造が円板端から外筒壁に向かって螺旋を描き, 反時計回りに伸 びている．実験における $u_{z}>0$ の領域（赤）は，図 $3 \mathrm{~b}, 3 \mathrm{c}, 3 \mathrm{~g}$ のように下降流から放射流へ優勢な状態が变化し 


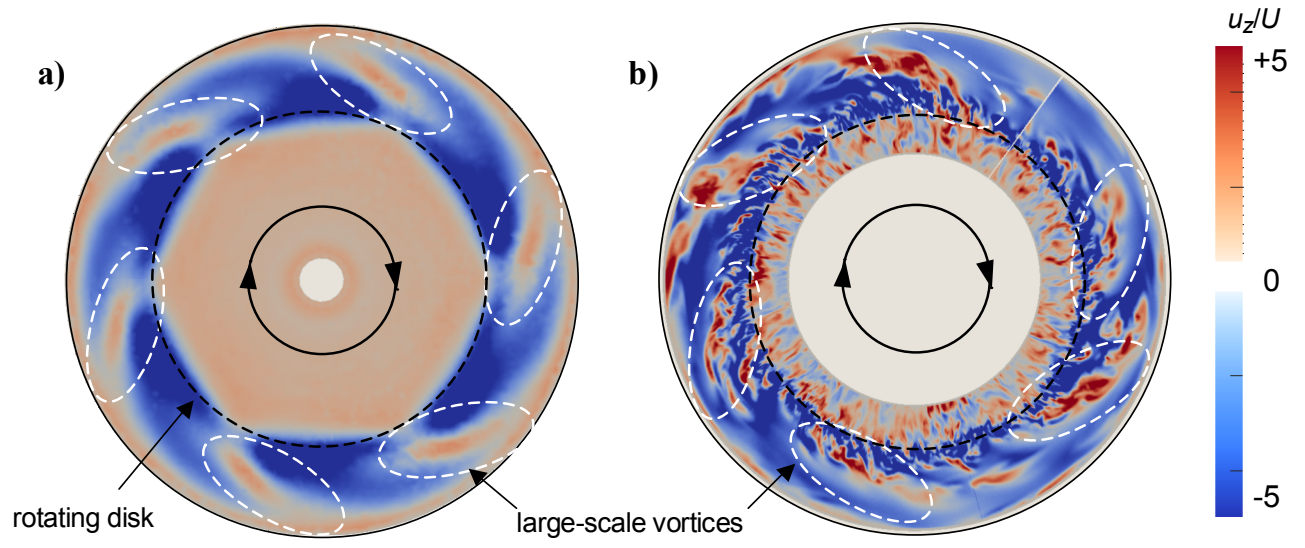

Fig. 7 The velocity component of $u_{z}$ in the $r-\theta$ plane at $z=-0.02 \mathrm{~m}$ obtained under the conditions of $U=0.04 \mathrm{~m} / \mathrm{s}$ and $\Omega=20.9$ $\mathrm{rad} / \mathrm{s}$. The three-dimensional spatial experimental data were reconstructed from the two-dimensional time- series PIV data by assuming Taylor's Hypothesis. The experimental data (b) well agreed with the computation (a).

た際に放出された渦の上向きの速度成分に起因寸る. また $u_{z}<0$ の領域（青）はこの渦の下向きの成分や渦が通 過し終わり，図3a，3d，3h のような放射流から下降流へ優勢な状態が移ったことに起因寸る. 実験データでは計 算とは異なり，滑構造を示寸赤色と青色の領域のペアは細かく分断され，小規模な渦が絡まり合い大規模な構造 をなしている. また実験では円板と排気カバーの間の領域や円板端近傍に多数の細かな渦構造が見える. 本 LES

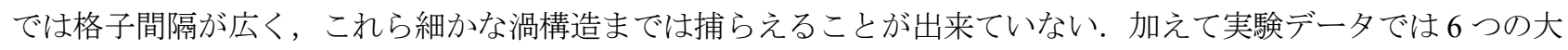
規模渦もその大きさが各々違っており，この渦が外筒壁に達している場合といない場合があることが分かる．大 規模渦が外筒壁に達すると,ここで強い巻上がりが生じ, それが比較的下流へと続く(外筒壁近傍の赤色の領域). また実験ではこれら渦の間隔も計算と比べるとやや不規則で, これが図 6 に見たスペクトルピークの幅の広がり を引き起こしている。

このように本研究を通じて, 洗浄機内流れに代表される回転円板とそれを囲う外筒および主流があるような流 れでは，円板端から容器外筒へ向かう大規模な旋回渦が安定なパターンを形成することが分かった．このような 渦構造はパーティクルの大規模な再循環を引き起こし, ウェー八表面へのコンタミネーションの再付着を引き起 こしうる. また下降流が支配的な大規模な螺旋渦の後流でも, 図 3a，3d，3h でみたように円板端で生じた小規模 な渦が円板端近傍に滞在するため, ウェー八外周近傍でのコンタミネーションの再付着を引き起こす可能性が高 い. そのため, 洗浄機にとってこの安定な大規模構造は好ましくなく, 今後この縦渦構造を壊していくことが, 装置の性能向上につながるであろう。この安定な渦構造は, 静止したケーシングの中で円板を回転させた場合

(Schouveiler, et al., 1999 や Gauthier, et al., 1999) や2つの回転円板内で挟まれた流体中に形成される洞構造 (Moisy, et al., 2004）と類似している. しかしながら, 現在のところ, なぜこのような大規模な安定構造が生じるのか, そ の明確な理由は分かっていない. 今後, このような安定なフローパターンが形成される原因の究明とそれに伴う この大規模構造の抑制方法の開発が望まれる.

\section{4. まとめ}

本研究では枚葉式シリコンウェー八洗浄装置内の 2 次元非定常 PIV 計測と 3 次元 LES を行い, 洗浄機内に形成 される 3 次元渦構造の推定を行った. 試験は装置上方からの空気流の下流レイノルズ数 $R_{D}=1.3 \sim 8.1 \times 10^{3}$, 円板 の回転レイノルズ数 $R_{r}=0 \sim 2.5 \times 10^{5}$ の条件で行った. なおこれは空気流の管断面平均流速 $U=0.04 \sim 0.24 \mathrm{~m} / \mathrm{s}$, 円板の角速度 $\Omega=0 \sim 136.1 \mathrm{rad} / \mathrm{s}$ の条件に相当する. また PIV 計測, LES とも渦構造の同定には速度勾配テンソル の第 2 不変量である $Q_{2}$ 值を用いた。

PIV 計測の結果より，円板の回転によりその端面から多数の渦が形成され，円板端から排気カバーへ向かう帯 状の渦領域が存在することが分かった。この渦領域は, 装置上方からの下降流が優勢で円板と排気カバーの間に 押し込まれている場合と，円板と排気カバーの間の流れの放射流が優勢になり外筒壁へ向かって放出さる場合に 
分けられ, これらが周期的に繰り返されていた.この現象の周波数は円板の回転数に比例して増加し, 例えば $U=$ $0.078 \mathrm{~m} / \mathrm{s}$ では円板角速度 $\Omega$ が $10.5 \mathrm{rad} / \mathrm{s}$ から $62.8 \mathrm{rad} / \mathrm{s}$ に増加すると, 周波数は $4 \mathrm{~Hz}$ から $12 \mathrm{~Hz}$ に増加した.

LES の結果により，この周期性は，洗浄機内に安定に生じる大規模な縦渦構造がゆっくりと回転することに起 因することが分かった. LES によれば $U=0.04 \mathrm{~m} / \mathrm{s}, \Omega=20.9 \mathrm{rad} / \mathrm{s}$ の条件では, 縦渦は洗浄機内の円板端から外筒 壁にかけて螺旋状に 6 つ存在しており, おおよそ移流速度 $3 \mathrm{rad} / \mathrm{s}$ で回転円板と同じ方向に回転していた. 計算と 実験を比較すると，この渦構造の移流に起因する速度変動の周波数は一致していた．またLES の結果より，この 安定な螺旋渦構造は $\Omega$ を変えても洗浄機内に同様に存在し, $\Omega$ の増加に伴いその移流速度も増加する.この傾向 は実験で観測された, 円板の回転数に比例して渦の存在領域が周期的に変化するその周波数の増加傾向と一致し ており，実験においても LES で得られた大規模構造が存在していると結論できる.

\section{謝 辞}

本研究の一部は, 岡山県の文部科学省補助事業「特別電源所在県科学技術振興事業」により実施した. また研 究に使用したハイスピードカメラ HAS-D72 は（株）ディテクトにお借りした。ここに謝意を表す.

\section{文献}

Di Prima, C. and Swinney, H.L., Instabilities and transition in flow between concentric rotating cylinders, Hydrodynamic Instabilities and the Transition to Turbulence, Topics in Applied Physics, Vol.45 (1985), DOI:10.1007/3-540-133194 _16.

enGrid - open-source mesh generation, available from <http://engits.eu/en/engrid $>$, (参照日 2015 年 5 月 1 日).

Gauthier, G., Gondret, P. and Rabaud, M., Axisymmetric Propagating vortices in the flow between a stationary and a rotating disk enclosed by a cylinder, Journal of Fluid Mechanics, Vol.386 (1999), pp.105-126.

服部 毅, 先端半導体洗浄技術の課題と展望, 表面技術, Vol.59, No.8 (2008), pp.526-532.

Hattori, T., Non-aqueous cleaning challenges for preventing damage to fragile nano-structures: A review, ECS Journal of Solid State Science and Technology, Vol.3, No.1 (2014), DOI:10.1149/2.010401jss.

Issa, R.I., Solution of the implicitly discretized fluid flow equation by operator splitting, Journal of Computational Physics, Vol.62 (1986), DOI:10.1016/0021-9991(86)90099-9.

Moisy, F., Doare, O., Pasutto, T., Daube O. and Rabaud, M., Experimental and numerical study of the shear layer instability between two counter-rotating disk, Journal of Fluid Mechanics, Vol.507 (2004), DOI:10.1017/S00221120 04008833.

NETGEN - automatic mesh generator, available from $<$ http://www.hpfem.jku.at/netgen/index.html>, (参照日 2015 年 5 月 1 日).

荻野文丸, 齊藤泰司, 松本初, 回転円板上淀み点流れの流動特性, 化学工学論文集, Vol.23, No.5 (1997), pp.713-719.

Schlichting, H., Boundary layer theory, 7th ed., translated by J.Kestin (1979), pp.102-107, McGraw-Hill.

Schouveiler, L., Gal, L.P., Chauve, M.P. and Takeda, Y., Spiral and circular waves in the flow between a rotating and a stationary disk, Experiments in Fluid, Vol.26 (1999), DOI:10.1007/s003480050278.

Scarano, F., Iterative image deformation methods in PIV, Measurement Science and Technology, Vol.13, No.1 (2002), pp. R1-R19, DOI:10.1088/0957-0233/13/1/201.

Seike, Y., DeNardis, D., Sugiyama, M., Miyachi, K., Doi, T. and Philipossian, A., Development and analysis of a high-pressure micro jet pad conditioning system for interlayer dielectric chemical mechanical planarization, Japan Journal of Applied Physics, Vol.44, No. 2 (2005), DOI:10.1143/JJAP.44.1225.

清水義也, 柳瀬眞一郎, 河内俊憲, 森洋平, 福田修也, 枚葉式半導体洗浄機モデル内渦構造の PIV 計測, 日本機械 学会論文集, Vol.80, No.815 (2014), DOI:10.1299/transjsme.2014fe0197.

Smagorinsky, J., General circulation experiments with the primitive equations: I. The basic experiment, Monthly Weather Review, Vol.91, No.3 (1963), pp.99-152.

The Open Source Computational Fluid Dynamics (CFD) Toolbox, available from $<\mathrm{http}: / /$ www.openfoam.com/>, (参照日 2015 年 5 月 1 日).

辻 義之, 田中宏彦, 大野哲靖, 流体乱流研究から診たプラズマ乱流のデータの解析 (4. 組織構造の定義とその抽 出），プラズマ・核融合学会誌，Vol.85, No.11 (2009), pp.774-782. 


\section{References}

Di Prima, C. and Swinney, H.L., Instabilities and transition in flow between concentric rotating cylinders, hydrodynamic instabilities and the transition to turbulence, Topics in Applied Physics, Vol.45 (1985), DOI:10.1007/3-540-13319$4 \_16$.

enGrid - open-source mesh generation, available from <http://engits.eu/en/engrid>, (accessed on 1 May, 2015).

Gauthier, G., Gondret, P. and Rabaud, M., Axisymmetric propagating vortices in the flow between a stationary and a rotating disk enclosed by a cylinder, Journal of Fluid Mechanics, Vol.386 (1999), pp.105-126.

Hattori, T., Problems and perspectives in leading-edge semiconductor wafer cleaning technology, Journal of The Surface Finishing Society of Japan, Vol.59, No.8 (2008), pp.526-532 (in Japanese).

Hattori, T., Non-aqueous cleaning challenges for preventing damage to fragile nano-structures: A review, ECS Journal of Solid State Science and Technology, Vol.3, No.1 (2014), DOI:10.1149/2.010401jss.

Issa, R.I., Solution of the implicitly discretized fluid flow equation by operator splitting, Journal of Computational Physics, Vol.62 (1986), DOI: 10.1016/0021-9991(86)90099-9.

Moisy, F., Doare, O., Pasutto, T., Daube O. and Rabaud, M., Experimental and numerical study of the shear layer instability between two counter-rotating disk, Journal of Fluid Mechanics, Vol.507 (2004), DOI:10.1017/S002211200 4008833.

NETGEN - automatic mesh generator, available from <http:/www.hpfem.jku.at/netgen/index.html >, (accessed on 1 May, 2015).

Ogino, M., Saito, Y. and Matsumoto, H., Flow near a rotating disc with stagnation flow, Journal of Chemical Engineering of Japan, Vol.23, No.5 (1997), pp.713-719 (in Japanese).

Schlichting, H., Boundary layer theory, 7th ed., translated by J.Kestin (1979), pp.102-107, McGraw-Hill.

Schouveiler, L., Gal, L.P., Chauve, M.P. and Takeda, Y., Spiral and circular waves in the flow between a rotating and a stationary disk, Experiments in Fluid, Vol.26 (1999), DOI:10.1007/s003480050278.

Scarano, F., Iterative image deformation methods in PIV, Measurement Science and Technology, Vol.13, No.1 (2002), DOI:10.1088/0957-0233/13/1/201.

Seike, Y., DeNardis, D., Sugiyama, M., Miyachi, K., Doi, T. and Philipossian, A., Development and analysis of a high-pressure micro jet pad conditioning system for interlayer dielectric chemical mechanical planarization, Japan Journal of Applied Physics, Vol.44, No. 2 (2005), DOI:10.1143/JJAP.44.1225.

Shimizu, Y., Yanase, S., Kouchi, T., Mori, Y. and Fukuda, N., PIV measurement of vortical structures in a model of semiconductor single wafer cleaner, Transactions of the JSME (in Japanese), Vol.80, No.815 (2014), DOI:10.1299 /transjsme.2014fe0197.

Smagorinsky, J., General circulation experiments with the primitive equations: I. The basic experiment, Monthly Weather Review, Vol.91, No.3 (1963), pp.99-152.

The Open Source Computational Fluid Dynamics (CFD) Toolbox, available from $<$ http://www.openfoam.com/ $>$, (accessed on 1 May, 2015).

Tsuji, Y., Tanaka, H. and Ohno, N., Plasma turbulence analysis from the view point of fluid turbulence (4. Coherent structures; its definition and extraction), Journal of Plasma and Fusion Research, Vol.85, No.11 (2009), pp.774-782 (in Japanese). 